\title{
Conserving the Richmond \\ Birdwing Butterfly over two \\ decades: Where to next?
}

\section{By Don Sands}

\section{Researchers and managers}

engage the broader

community to assist with

babitat expansion for this

declining butterfly
Don Sands is an Honorary Fellow with CSIRO Entomology (120 Meiers Road, Indooroopilly, Qld 4068, Australia; Tel. (O7)32142803, Email: don.sands@csiro.au). This article arose from a need to address threats to the Richmond Birdwing Butterfly by taking advantage of community actions to save this Australian flagship invertebrate.
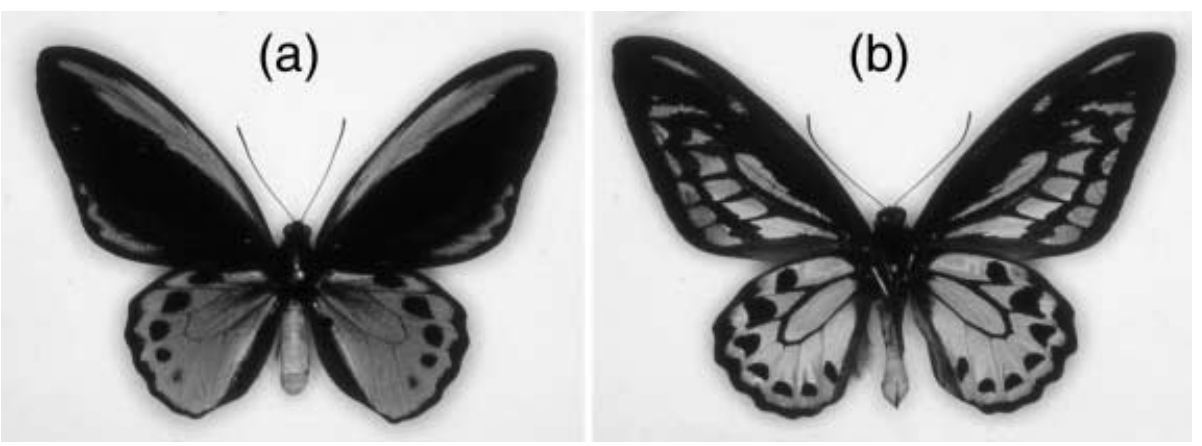

Figure 1. (a) Upperside and (b) underside of the male Richmond Birdwing. The brilliant colouring and large size of Birdwing Butterflies (of which there are $\mathbf{3 0}$ worldwide and three in Australia) has led to over-collecting of some species. Habitat destruction, however, is an equally serious threat to their conservation. In Queensland, Australia, all three native birdwings are listed as 'protected species' and a programme of habitat conservation for the Richmond Birdwing is well underway.

\section{Introduction}

ustralia's disappearing macrofauna Thas recently received increasing attention by conservationists but most people spare little thought to the extinctions of Australia's 'microfauna', the invertebrates. Despite making up around $99 \%$ of the animal kingdom (Ponder \& Lunney 1999), invertebrates have been largely 'left off the agenda' . Many are seemingly difficult to observe and identify, their biology is far more complicated than vertebrates and most are not considered during the preparation of conservation plans.

Some insects, mostly butterflies (the best known and recognized of the insect groups), have been selected as 'flagships' to convey the plight of threatened invertebrate species. Projects on butterflies and moths in Australia have paved the way for developing invertebrate conservation and recovery actions. The first was in 1988 in Victoria, on the Eltham Copper (Paralucia pyrodiscus lucida) after it was thought close to extinction (Sands \& New 2002a). Other conservation projects followed, mostly targeting species of the 'blue' butterflies (Lycaenidae) (Payne \& LundieJenkins 1999; Nally 2000).

\section{Threats to the Richmond Birdwing and its habitats}

The Richmond Birdwing (Ornitboptera richmondia Gray) (Fig. 1 and Box 1) occurs only in subtropical northern New South Wales (NSW) and south-east Queensland. It has experienced declines across its range from rainforest clearing (Fig. 2). Although not considered threatened in NSW, it is now listed as 'Vulnerable' to extinction under Queensland's Nature Conservation Act (1992). Continuing 


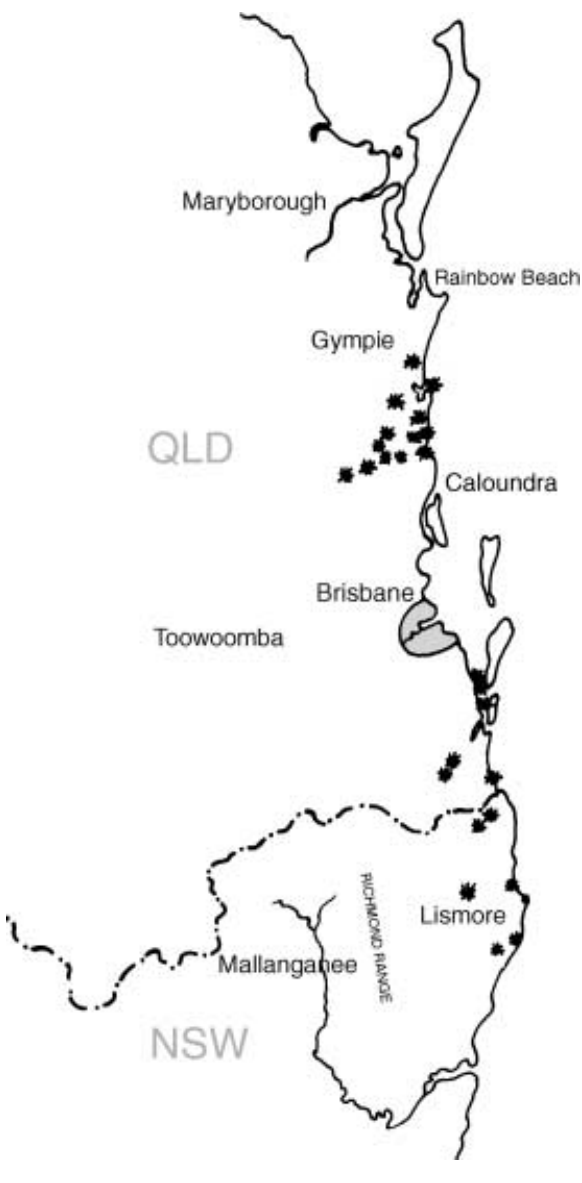

declines in abundance and distribution of the butterfly have occurred over the last 20 years in Queensland and only recently, 'threat abatement' programmes have been developed for threatened species in the State.

The initial threat, clearing of lowland rainforest for forestry and farming, has now stopped; but urban development continues as the primary threat to the Richmond Birdwing as it destroys already fragmented habitats of its food plant vine (Box 1), with roadside patches particularly vulnerable. Invasive weeds (including vines such as Morning Glory (Ipomoea spp.) and Madeira Vine (Anredera cordifolia)) are also important threats-with the South American

Figure 2. Observation records for Richmond Birdwing Butterfly larvae on its lowland food vine in New South Wales and south-east Queensland, 2002. The species natural range extended from the coast to Toowoomba and the Richmond Range - and from Maryborough in the north to Grafton in the south. This range has severely contracted in the last century with extensive clearing of rainforest habitats.
Dutchman's Pipe (Aristolochia elegans) Vine being particularly problematic as its leaves are poisonous to larvae of the Richmond Birdwing and some other butterflies when they are decoyed into laying their eggs on the vine (Straatman 1962). Burning of rainforest during fuelreduction and grazing management regimes has also destroyed some habitats. To this day in Queensland, destruction of threatened rainforest fragments by clearing, underscrubbing or burning occurs and is allowed on privately owned land where fragments are not officially mapped or too small to qualify as 'Threatened regional ecosystems'.The Richmond Birdwing Vine is sometimes also cut down or removed although it is recognized as a rare and protected species in Queensland.

A recent threat, prolonged drought, has placed added pressure on the Richmond Birdwing in south-eastern Australia. Drought has increased mortality of the species' immature stages by affecting the quality of the food plant and making the leaves too tough and unpalatable for the larvae (Sands et al. 1997).

\section{Box 1. Biology of the Richmond Birdwing}

Birdwing Butterflies (Swallowtail Butterflies: Papilionidae) are among the largest and most beautiful butterflies in the world. Their size, colours and biology have attracted attention from community members, scientists, butterfly collectors, environmentalists, insect breeders, and traders in specimens. In several countries including Indonesia, Papua New Guinea and the Solomon Islands, Birdwing Butterflies have been farmed for at least 40 years to meet demands from the collectors of specimens (New 1997).

There are more than $\mathbf{3 0}$ species of Birdwing Butterflies known from southern Asia, the Indonesian islands, Papua and Papua New Guinea, the Solomon Islands and eastern Australia. Of these, three are recognized in Australia: the Cairns Birdwing (Ornithoptera euphorion), the Cape York Birdwing (Ornithoptera priamus) and the Richmond Birdwing (Ornithoptera richmondia). The Richmond Birdwing (from subtropical Australia) and the Queen Alexandra's Birdwing (from Papua New Guinea) are the Birdwing Butterflies considered most threatened by a continuing loss and declines in numbers of their food plants, fragmentation and lack of secured and protected habitats (Parsons 1992; Sands et al. 1997)

The Richmond Birdwing is smaller than the other two Australian species, but like them, the males have green (very rarely blue) areas on the upperside of both wings and blue, green and gold patches on the underside of the hind wings. Adult Richmond Birdwings vary considerably in size, with males, the more colourful, having a wingspan of $11-13 \mathrm{~cm}$ and the females having a wingspan of 14-16 cm. Larval food preferences. The food plants of the larval stage of the Richmond Birdwing Butterfly are two rainforest vines, the Birdwing Butterfly Vine (Pararistolochia praevenosa) and the Mountain Aristolochia (Pararistolochia laheyana) (family Aristolochiaceae.) These are the only locally occurring plants on which the female will deposit eggs and the larvae will consume to successfully develop to pupating stage (Fig. 3). Sands and Scott (2002) suggested 10 vines per habitat patch may be sufficient to sustain the butterfly. Since prolonged drought, this has been revised 
to 30 vines per habitat patch (D. Sands, unpublished data 1992-1997) Adult nectar preferences. Adults of Richmond Birdwing feed on many nectar-bearing exotic and native flowers, preferring white, cream or red blooms to other colours. Examples of native flowers include Native Frangipani (Hymenosporum flavum), Syzygium spp., Eucalyptus spp., Brush Box (Lophostemon confertus), Whip Vine (Flagellaria indica), Pink Euodia (Melicope elleryana), Red Silky Oak (Alloxylon pinnatum), Black Bean (Castanospermum australe), Blue Quandong (Eleaocarpus grandis) and Grevillea spp. Richmond Birdwing has been seen visiting many introduced flowers in gardens (including Bougainvillea (Bougainvillea spectabilis), Agapanthus (Agapanthus praecox), Buddleja (Buddleja davidii), Bauhinia (Bauhinia variegata), Honeysuckle (Lonicera japonica) and Impatiens (Impatiens spp.), and the invasive weed Lantana (Lantana camara). Adult Richmond Birdwing does not feed on the nectar from flowers of the larval food plants, Pararistolochia spp.

The adult Richmond Birdwings live for about 4-6 weeks and have few natural enemies other than spiders, wasps and occasionally birds, such as Noisy Pitta (Pitta versicolor). The flying periods for Richmond Birdwing are the warmer months from September to April on the coast and November to February in the mountains of the Queensland-NSW Border Ranges but occasional sightings of adults have occurred at other times of the year. There are two main generations (bivoltine) per year on the coast and one (univoltine) at higher altitudes. On the coast, adults commence emerging from over-wintering pupae (in diapause) in spring (September-October) and some continue emerging into summer. Pupae forming in late spring or early summer of coastal populations do not normally enter diapause unless stressed by drought, and they produce adults in late summer and autumn (January-March). There is sometimes an overlap with adults emerging from over-wintering pupae and those of spring generations. Pupal diapause is initiated by decreasing day length and terminated by an increase in day length, temperature, rainfall and possibly other factors. At the higher altitudes in the Border Ranges, adult birdwings emerge in summer (mostly December-January).

Adults and the immature stages of the Richmond Birdwing have remarkable few natural enemies when compared with other butterflies or even other birdwings. Sands and Scott (2002) recorded a range of predatory spiders, wasps, beetles, bugs, mites and some birds but they proved to be insignificant when compared with the impacts of unpalatable leaves and inbreeding depression. Prolonged drought can be blamed for the most recent declines in distribution and abundance of the moisture-adapted Richmond Birdwing. Prolonged drought is a threatening process for the butterfly with its impacts on the quality and phenology of the food plant (especially toughening leaves) exacerbating processes causing inbreeding depression in the fragmented landscapes.

(Basic information on the life history of the Richmond Birdwing published by Waterhouse (1932) was updated by Common and Waterhouse (1981) and Sands et al. (1997). Recent information on the food plants of several butterflies and moths was found in Braby (2000) and Zborowski and Edwards (2007).)
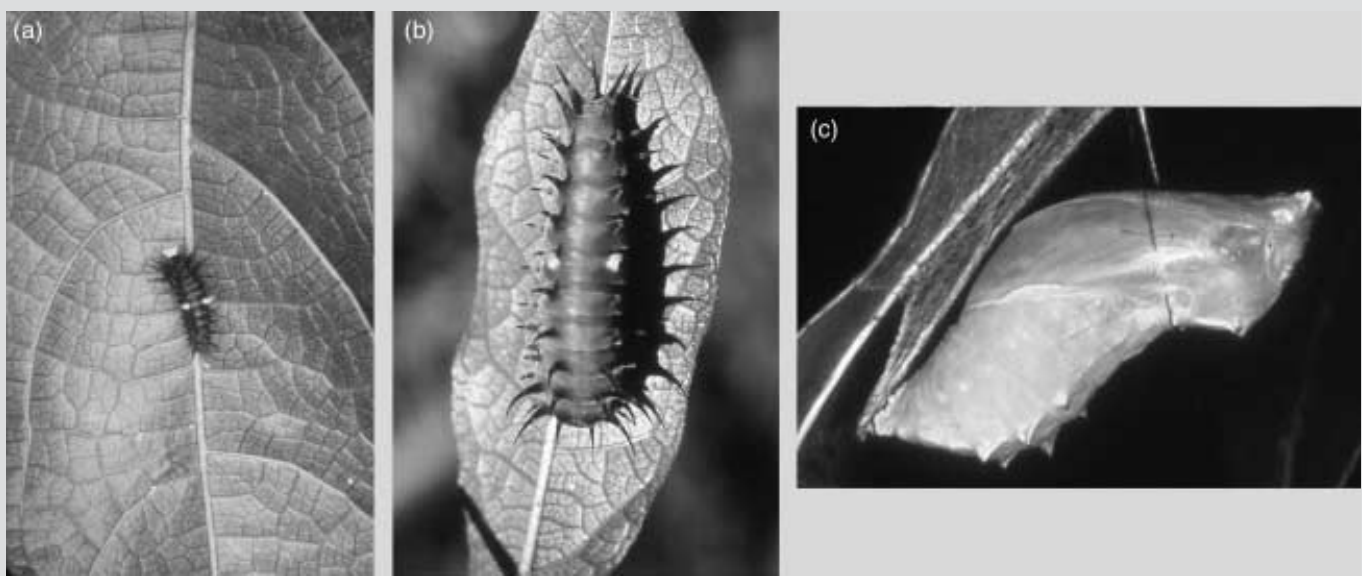

Figure 3. (a-c) The female Richmond Birdwing lays her eggs almost exclusively on the Richmond Birdwing Vine, which is itself not well conserved. With favourable moisture conditions to avoid leaves hardening, the larvae will consume the leaves and develop to full size and successfully pupate. (Note the pupa of this species is green and, unlike other birdwings, is reinforced by a flat silken pod.) The adults commence emerging the following spring. 


\section{Distribution: Past and present}

While the natural northern extent of the Richmond Birdwing and its lowland food plant (Box 1) was originally Maryborough and Gympie, Queensland, and its southern extent was Grafton on the Clarence River, NSW (Rainbow 1907; Waterhouse 1932; Haugam \& Low 1979) (Fig. 2), the butterfly became very rare at these range extremes by 1932 (Waterhouse 1932). The natural western extent ranged from Toowoomba in south-east Queensland (last confirmed in 1964, J. Macqueen, pers. comm.) to the Richmond Range in northern NSW where it still occurs at Cherry Tree National Park (Mallanganee) (Sands \& New 2002a). The butterflies were once common near Brisbane, Queensland and in the suburbs. Historically, adults were reported in the streets of Brisbane in 1870 (Illidge 1927); and, in 1883, thousands were seen in the Blackall Range, north of Brisbane (Waterhouse 1932).

Declines in abundance of the Richmond Birdwing began in the 1900s (Illidge 1927; Waterhouse 1932) and have continued since (Sands \& Scott 1999). As the northern edge of distribution has contracted, declines in populations of the butterfly and its food plant have continued until less than two-thirds of the original population's range remains. This is linked to a decline in the number of individual habitats in south-eastern Queensland and northern NSW. Since about 1980, the butterfly has not been confirmed between Gympie and Maryborough, on the Main Divide from Cunninghams Gap to Toowoomba, Queensland, or on the Clarence River, NSW.

At the northern edge of this contracting range, the butterfly became extinct at Kin Kin Creek (c. 2003) and most of the coastal populations north of Brisbane have been destroyed. By 2007, in Queensland, populations breed in the Connondale and Blackall Ranges, between Eumundi, Bli Bli and Beewah, at Mount Mee on the D'Aguilar
Range and south of Brisbane, from Nerang to the Tallebudgera Valley. In northern NSW, habitats of the Richmond Birdwing appear to be secure from the Tweed River to Wardell, at the base of the Richmond Range and west near Mallanganee, particularly since several national parks and other tenured reserves support populations of the butterflies and their larval food vines.

\section{The Richmond Birdwing Butterfly project}

\section{Genesis and evolution}

The Richmond Birdwing conservation project was initiated in 1989 after discussions between Bob Moffatt, an NSW National Parks and Wildlife Officer, and Don Sands, a CSIRO entomologist. They met when visiting Broken Head National Park, northern NSW, one of the very few coastal habitats supporting sufficient abundances of the Richmond Birdwing larvae's food plant, the lowland Birdwing Butterfly Vine (Box 1). Earlier, Sands (1962) proposed that the food plant might be propagated in sufficient numbers to encourage the butterflies into urban areas, referring to successes with the Cairns Birdwing (Ornitboptera eupborion) in northern Queensland. Bob and Don agreed to look closely at these challenges for recovery of the Richmond Birdwing questioning, 'How can this be done', and 'can community or school students become involved'?

In the early 1990s, Bob and Don talked to community and school groups, outlining the plight of the Richmond Birdwing and causes of its decline. They advocated planting the Birdwing Butterfly Vine as a means to offset loss of wild vines. Several schools began planting and a plant nursery, Balunyah Nursery, Coraki, in northern NSW began propagating the vine commercially (Box 2). The CSIRO Double Helix Science Club, led by Sue Scott in Brisbane, introduced the developing conservation project to their series of school science studies and over a period of 5 years, it became a 'handson' invertebrate study for students in Queensland and continued until Sue and Don retired from CSIRO in 1997. Further declines in the Richmond Birdwing Butterfly first became apparent during prolonged drought in 1997 and in the years that followed, several community members requested renewal of the Richmond Birdwing conservation programme.

People who planted food plant vines some years earlier began to notice butterflies breeding in their gardens and they wanted advice about growing more of the food plants to attract them. Sue Scott and Don Sands formed a new community group in 2005, the Richmond Birdwing Recovery Network Inc. (the Network), adopting several activities from the Double Helix Science Club project, especially a need to cultivate more food plants. The Network invited membership from interested community members, local governments, environmental branch representatives, Queensland's Environment Protection Agency, and all interested members of environmental organizations. In 2006, it became incorporated and by December 2007 , its membership had increased to more than 300 members.

\section{'Fact-finding' activities}

Systematic efforts towards conservation of the Richmond Birdwing Butterfly were made by reviewing the published and unpublished knowledge relating to the taxonomy, biology and distribution of the butterfly and its food plants, and exploring ways to involve the community in conservation activities that might lead to recovery.

First, it was important to assemble records of decline in distribution and abundance of the Richmond Birdwing as these provided a basis for validating threats to the species, particularly the extinction-threatening rate of decline in south-eastern Queensland.We found that localities where the butterfly was traditionally known to breed (e.g. near Noosa and Coolum) were being progressively disturbed and developed 


\section{Box 2. Community and school programmes}

New (2002) described Birdwing Butterflies as '. . . spectacular, exotic and impressive even to many people with little interest in insects. As such, they have become important ambassadors for invertebrate conservation. . . Since about 1992, Richmond Birdwing populations have been monitored by enthusiastic community members and school students associated with the Double Helix Science Club, through observing the butterfly larvae on planted vines. Finding out how to 'propagate sufficient food plants for schools to plant' was the first challenge. A source of planting stock of the Birdwing Butterfly Vine had to be found. To address these needs, in 1989, about 600 seedlings raised by Don (from seed collected from wild plants between Nerang and Tamborine Mountain, Queensland and near Lismore, NSW) were potted up by Bob Moffatt and delivered to Balunyah Nursery, Coraki, northern NSW. This founder culture at the nursery became the source of most vines distributed over the next few years. In 1991, Bob provided 40 schools in the Richmond Valley with six vines each to plant in their school grounds and the success of this project laid the foundation for habitat restoration work elsewhere. With enthusiastic staff, one small country school (Modanville Public School, near Lismore) led a 'flagship' project for restoring habitats for the Richmond Birdwing Butterfly as considerable community interest followed when Richmond Birdwing Butterflies appeared on the planted vines at the school.

In 1992, Don invited the Double Helix Science Club in Brisbane, led by Sue Scott, to become involved in coordinated planting of vines at schools in northern NSW and south-eastern Queensland. By 1994, 130 schools had joined the Richmond Birdwing Butterfly project. Sue guided the school students and helped them set up experiments on vine growth, in particular leaf toughness, which was found to affect the survival of young larvae. From 1994 onwards, she developed school agendas for the Richmond Birdwing with the interest expanding in 1997, until more than 300 schools were involved in the programme and more than 29000 vines had been distributed. One very successful school project, the 'Adopt-a-caterpillar Scheme' aimed to introduce 'hands-on' practical studies and provide an opportunity for students to handle and rear larvae through to adults. Information on their development was kept until the emergence of the adults which were then released. A notable presentation on behalf of CSIRO was given to an international audience of journalists at the 2000 Olympic Games in Sydney, Australia. Don and Sue described community and student participation in the Richmond Birdwing project from its beginning and exhibited two adults of the butterfly as they emerged from pupae.

(Sands \& Scott 2002), leading to a broad-scale loss of habitat, food plants and corridors. We also found sterility of eggs and deformity of young larvae (resembling indicators of inbreeding depression noted and predicted by Orr 1994) occurring in isolated habitats such as in Burleigh Heads National Park and at Kin Kin Creek. Subsequently, evidence from the field has confirmed how this problem was manifesting from habitat fragmentation.

Second, the tenure and security of the remaining habitats needed examination. After reviewing published and unpublished information, we became aware that the lowland food plant vine was poorly conserved in south-eastern Queensland (Forster et al. 1992), particularly on the coast and lower ranges, and its numbers and representation in formal reserves were insufficient to sustain healthy breeding by the butterfly.
Known refuges were being further fragmented and isolated after 2002 and movement of adults from one breeding site to another was being prevented by lack of 'green' corridors. In NSW, numbers of secure breeding localities were adequate but weed displacement of the food plant vines had begun and continues to threaten many of the habitats (R. Moffatt 1997, pers. comm.).

Third, the identities and distribution of the food plants for the Richmond Birdwing (see Box 3) needed examination. We found that distribution of the lowland Richmond Birdwing Vine was in rapid decline and it had become a rare plant everywhere in Queensland. Although habitats of the Mountain Aristolochia Vines all remain secure in the Border Ranges National Parks, this vine is not a sustainable food plant for the butterfly because Richmond Birdwing has never been able to survive the mostly cold and dry winters above $600 \mathrm{~m}$ and so survival and recolonization in these habitats is erratic. Breeding by the Richmond Birdwing on the Mountain Aristolochia was last recorded on the Queensland/NSW Border Ranges in 1994, based on presence or absence of immature stages (S.Scott, pers. comm.).

Fourth, the suspected threatening processes needed to be clarified so that threat abatement strategies could be developed. We found that the most serious of these threatening processes was the invasive weed, the Dutchman's Pipe Vine, a garden escapee (Fig. 4). Everywhere it was present, dead larvae of the Richmond Birdwing were seen, including in national parks. Originally from South America (Stanley \& Ross 1983; Harden et al. 2007), this vine attracts egg lay by females but is poisonous to the larvae when they 


\section{Box 3. Birdwing vines and their ecology}

When the Richmond Birdwing project gained momentum in 1992, little information was available on the ecology of rainforest vines in subtropical Australia generally, much less the two food plants. But since then, habitats of the two species of Pararistolochia have been examined, the information applied to cultivation and used when the vines were planted at rainforest restoration sites or in gardens, providing important insights for designing recovery actions for the butterfly.

Observations on the vines between 1989 and 2007 were constantly being updated by members of the community, to maximize the chances of restoring and protecting natural habitats, and cultivating a breeding environment for the butterfly. The following information summarized since the project began, has been widely distributed to members of the community, through newsletters and newsletter supplements and the community workshops. The identities of the vines were made by reference to Stanley and Ross (1983), Williams and Harden (1980), Parsons (1996) and most recently, Harden et al. (2007).

The ecosystems currently, or previously (most likely) supporting the Birdwing Butterfly Vine are based on the soil types: (i) Quaternary alluvials (most with basaltic floaters); (ii) Tertiary and interbedded volcanics (basalt); (iii) igneous; and, (iv) parabolic high sand dunes (mostly over basalt). At higher altitudes on the Queensland/NSW Border Ranges, the ecosystems supporting the Mountain Aristolochia ( $P$. laheyana) are on Tertiary volcanics (basalt or rhyolite).

Birdwing Butterfly Vine. The lowland food plant of the Richmond Birdwing occurs in rainforest to about $600 \mathrm{~m}$, growing among rocks on basaltic slopes, in basaltic soils on ridges, on rhyolite slopes, and often riparian embankments with alluvial soils. It is found rarely on nutrient-rich sand dunes. Mature stems are $1-5 \mathrm{~cm}$ in cross section ascending to $20 \mathrm{~m}$ but usually 10-15 $\mathrm{m}$. The stems frequently fuse with other ascending stems. The bark has a distinctive reticulated pattern. Alternate mature, dark green leaves are tough but young, paler green leaves are soft with a few fine hairs, becoming firmer and smoother with ageing. Leaf toughness varies with age of the growth. Only soft leaves are palatable to larval instars 1-3. Apical growth is not eaten by larvae until instar 3 when larvae then consume the apex and alternatively the leaves and stem.

Light is a stimulus for the seedlings of under rainforest canopies which otherwise remain dormant. Light must be considered when planting the vines in heavily shaded areas and sometimes the 'ideal' sites where mature vines tend to grow are too shaded for growth by young planted vines.

Pollination, seed development and seed dispersal

Flowering occurs from late September to December. The pollinators are undescribed species of midge (Forcipomyia spp.) believed to breed in moist leaf litter (G. Monteith, pers. comm.). Individual plants vary in number of flowers produced and seed capsules developing. Few flowers become pollinated under the rainforest canopy and seed capsules develop more frequently when plants are exposed either at edges or in the upper canopy. The green seed capsules expand and ripen over summer, turn bright yellow to orange and fall from the vine in autumn, often fracturing on impact. Each capsule $($ c. $2.3 \times 1.2 \mathrm{~cm}$ ) contains about 60 flattened seeds which remain viable after fracture for only a few weeks unless kept moist in soil or leaf litter. The Australian Brush Turkey (Alectura lathami) disperses seeds by breaking open the capsules with their claws to feed on the pulp (Sands \& Scott 2002). Seeds germinate in cohorts, resulting in clumps of seedlings. Silvereyes (Zosterops lateralis) have been seen to feed on the fruit (Sands \& Scott 2002) but their role in seed dispersal has not been determined.

Other associated vines. Certain vines (Table 1) were associated with the Birdwing Butterfly Vine and these natural 'companion vines' proved to be valuable indicators for 'where to start searching' for the food plant in rainforest. Understorey growth of these vines provided suitable habitats for monitoring feeding by the butterfly larvae when vertical 'water shoots' of Birdwing Butterfly Vine (with leaves) formed part of the complex of ascending vines.

Table 1. Vines in south-eastern Queensland associated with lowland Pararistolochia praevenosa*

\begin{tabular}{lll}
\hline Species & Ecosystem & Association* \\
\hline Flagellaria indica & Basaltic slopes, riparian, nutrient-rich sand dunes & Common \\
Calamus muelleri & Basaltic slopes, riparian & Common \\
Trophis scandens & Basaltic slopes, riparian & Common \\
Cissus antarctia & Riparian & Frequent \\
Callerya megasperma & Riparian & Frequent \\
Carronia multisepalea & Basaltic slopes riparian & Frequent \\
Melodorum leichhardtii & Basaltic slopes, riparian, nutrient-rich sand dunes & Occasional \\
Cissus hypoglauca & Riparian & Occasional \\
\hline
\end{tabular}

*Based on summary of observations: 1992-2002. 
Mountain Aristolochia. The mountain food plant is restricted to the Queensland-NSW border Ranges (above $600 \mathrm{~m}$ ). In NSW, it occurs on Mount Nardi in the Nightcap Range, the Richmond Range and on the summit of Mount Warning. In Queensland, it is abundant at Springbrook, Binna Burra, O'Reilly's and the Western Rim of the McPherson Range. It may have occurred on the Main Divide near Cunninghams Gap where Richmond Birdwings have been seen in past years. There is a single record of the Mountain Aristolochia from near Toowoomba (H. Krenske, unpubl.) but a voucher specimens has not been available to confirm identification.

Mountain Aristolochia is a much smaller vine when compared with the Birdwing Butterfly Vine, and is often found entwined in low growing shrubs, sometimes ascending to $5 \mathrm{~m}$. The leaves of the Mountain Aristolochia are smaller, smooth above and softer than Birdwing Butterfly Vine. Flowers of the Mountain Aristolochia have been observed from February to October and are about 20-30 mm long with a swollen base. The seed capsules are subparallel sided, ribbed and greenish-yellow when ripe. They are known to be only distributed mechanically by Brush Turkeys.

Flowers do not produce nectar but definitely produce some attractant to the pollinating midges. Between 2001 and 2005 , the flower contents of both species were examined and the identities of midges suggested strongly that they were mostly males and each vine contained different species of midge. These observations have led to the hypothesis that a 'pseudopheromone' or allomone mimicking the midge pheromone may be inducing entry and subsequent pollination when midges move from one flower to another (Sands, pers. obs. 2005/2006).

A very small plant, Aristolochia meridionalis occurs naturally in open woodland in south-eastern Queensland as a prostrate, low-growing vine with only several stems (Ross 2007). There is a possibility that the Richmond Birdwing may feed on A. meridionalis where plant numbers are adequate for supporting larvae. One hypothesis is that the easily overlooked A. meridionalis could be the occasional food plant of the Richmond Birdwing in the Border Ranges where the two species of Pararistolochia have not been identified as occurring naturally.

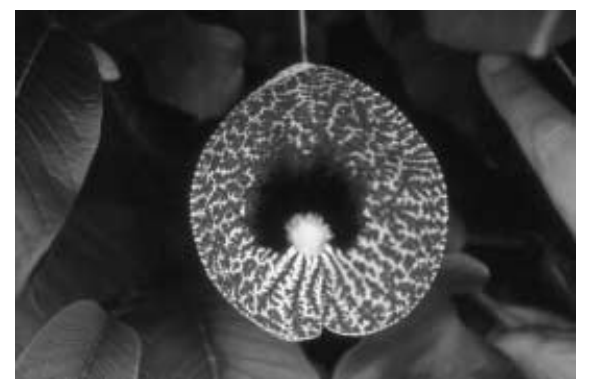

Figure 4. The exotic Dutchman's Pipe Vine (botanically related to the Richmond Birdwing Vine) is a particular threat to the Richmond Birdwing as the females are attracted to lay their eggs on it. However, the leaves of Dutchman's Pipe are fatal to Richmond Birdwing larvae and the vine is an important target for removal in all rainforest restoration programmes in the Richmond Birdwing's range.

feed on the leaves after hatching. Dutchman's Pipe Vine continues to threaten the survival of the butterfly, especially now that climate change may favour the competitiveness (and expand the range) of this and some other invasive weeds (Raven \& Yeates 2007).
We also considered the question of whether our main proposal for threat abatement (i.e. collecting propagation material of the larval food vine from a relatively smaller range of sites and distributing them across the species' range) would have any deleterious impact on the food plants in the wild. Advice was sought on genetic issues relating to propagation of the Birdwing Butterfly Vine. Ms Estelle Ross (Queensland Herbarium) reviewed the variation in morphology of Birdwing Vine specimens, pressed and living, from between Wardell and Mallanganee, north-eastern NSW, and between Tamborine Mountain and Rainbow Beach, south-eastern Queensland. (Specimens from the outlying population of the Birdwing Butterfly Vine from Atherton Tablelands (recorded by Harden et al. 2007) were not examined and no live or preserved specimens were available for examination from the northern localities between Rainbow Beach and Mary River Heads or southern localities near Grafton, NSW.)
In Ms Ross's opinion, all morphological variation observed in the range of populations of the Birdwing Butterfly Vine was insignificant and likely to be the result of phenotypic plasticity rather than fixed genotype differences, although techniques to study genotypic variation were not then so readily available. As the historical connectivity between populations of vines allowing gene flow has in most parts of the range been severed, inbreeding depression was considered to be more likely a potential problem for the wild vine populations than outbreeding, which was not considered to be of concern. Nonetheless, care was taken to collect propagation material from multiple wild vines in widely spaced sites in both Queensland and NSW. (See later section 'Genetic and propagation issues'.)

\section{Current activities and progress to date}

The main activities of the group are to conserve the Richmond Birdwing 


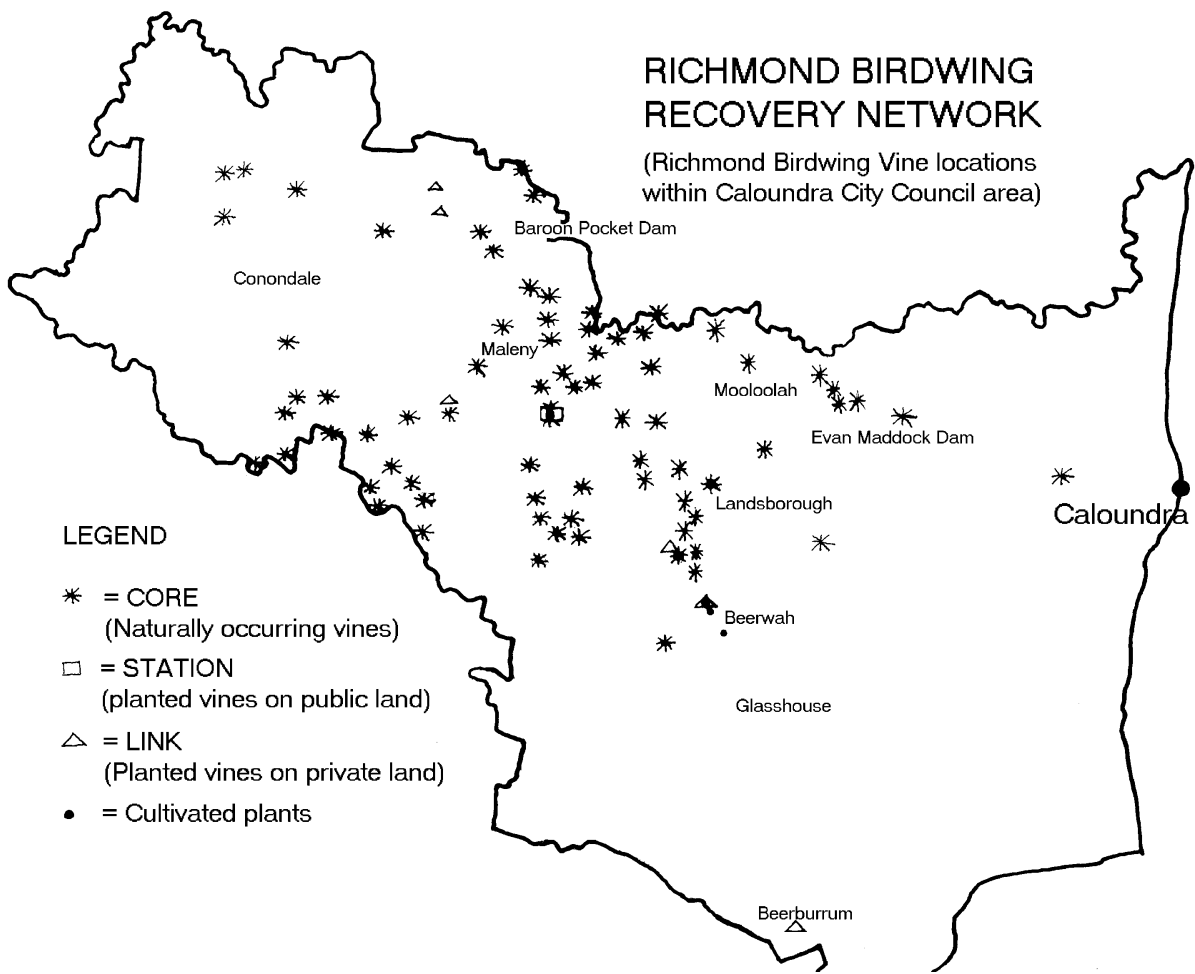

Figure 5. The Network has established a database of naturally occurring and planted vines, with records existing for 10 districts in south-east Queensland. These records are being used as the basis for establishing corridors suitable for habitat enhancement.
Butterfly by protecting, propagating and planting food vines in their native range, to remove the Dutchman's Pipe Vine and to map and encourage the better management of remaining habitats where wild vines are growing naturally. A range of actions to date are detailed in the following paragraphs.

\section{Cultivation and distribution of food plants}

Building on the success of the earlier school plantings (Box 2), Richmond Birdwing conservation efforts are ongoing in northern NSW and continue to be topics for local seminars or at major community events in NSW such as the Big Scrub Rainforest Days (sponsored by Rainforest Rescue and the Big Scrub Rainforest Landcare Group). There appears no major decline in Richmond Birdwing abundance or its distribution in northern NSW in recent years, but community groups and home gardeners are being encouraged to plant the Birdwing Butterfly Vine at suitable riparian or other bush regeneration sites in an effort to overcome past reductions.

In Queensland, members of the Network, affiliated Landcare and other groups, have been encouraged to plant vines in corridors at privately owned bushland sites and in gardens (referred to as 'links'), or public land (referred to as 'stations') to provide breeding sites for the Richmond Birdwing and breach the gaps in fragmented habitats to prevent inbreeding depression. On the Sunshine Coast, for example, more than 1500 Birdwing Butterfly Vines have been planted on 22 privately owned properties (links) and on 13 sites on Council-owned land (stations) from Noosa to Beerwah to December 2007. Similarly, south of Brisbane and on the Gold Coast more than 5000 Birdwing Butterfly Vines have been planted in stations and links from Tamborine Mountain to Tallebudgera and at Canungra.

\section{Nursery expansion}

Based on the experience with cultivation of the vines by Balunyah Nurseries in the 1990s, several community nurseries participated with the Network in growing vines of the highest quality and to develop methods most likely to ensure their survival after planting out. Four plant nurseries participated in a coordinated, non-profit plan to provide sufficient food plant vines for planting and rehabilitation of habitats, for gardens and private land. From 2005 until 2007, the estimated number of vines produced under this scheme exceeded 5000 vines.

Recording and mapping food plants for corridor linkages

Coordinated plantings of food vines from Maryborough Queensland to Grafton, NSW and west to Toowoomba have been recorded. Details of locality (including global positioning system coordinates), date and number of vines planted are being entered into the Network's database. Important information is also recorded on wild vines and changes in their number and distribution (Fig. 5) - as well as presence and absence of the Richmond Birdwing Butterfly. (Note: Localities with wild vines are distinguished from those with planted vines on the basis of the age of vines and whether records for planting in the past exist for that site.) Using the Network's database program, basic entries can be accessed through the internet and approved Network members can add their new records.

The locations of each site were compiled for each municipality or local 
district as the basis for establishing corridors suitable for dispersing adults, for breeding and for genetically enhancing otherwise fragmented breeding habitats. The first corridors were established in the Western Suburbs of Brisbane, Toowoomba and Caloundra Shires, followed by others in Noosa, Maroochy, Beaudesert and Gold Coast Shires. Such corridors are expected to be the most promising recovery actions and likely to minimize inbreeding depression.

Sites are regularly monitored for survival of vines and presence of larvae or feeding scars. Monitoring methods were also developed based on leaf age, to estimate when butterfly larvae were last feeding on particular vines.

\section{Corridor coordinators and partnerships}

Corridor coordinators appointed by the Network members work closely with the community members and the municipal councils' Land for Wildlife officers. Cooperative activities include local cultivation and distribution of vines, locating wild vines and mapping and planting vines in corridors (Fig. 6). Corridor coordinators establish stations and links, help with school projects, encourage nursery cultivation and carry out fertilizer trials or other field work, such as the removal of Dutchman's Pipe Vine.

On the Sunshine Coast, the Land for Wildlife programmes have, with support from local councils, contributed to disseminating awareness of the Richmond Birdwing, its food plant and habitat needs. Land for Wildlife property owners are protecting their habitat fragments in an effort to stabilize populations of the butterfly. In Caloundra Shire alone, more than 160 properties have joined this scheme and their Richmond Birdwing habitats have been mapped (Fig. 5). Maroochy and Noosa Councils are also supporting similar schemes. Several property owners have 'enriched' their habitats by planting cultivated vines to provide additional food plants when vine abundance was low. The benefits of these

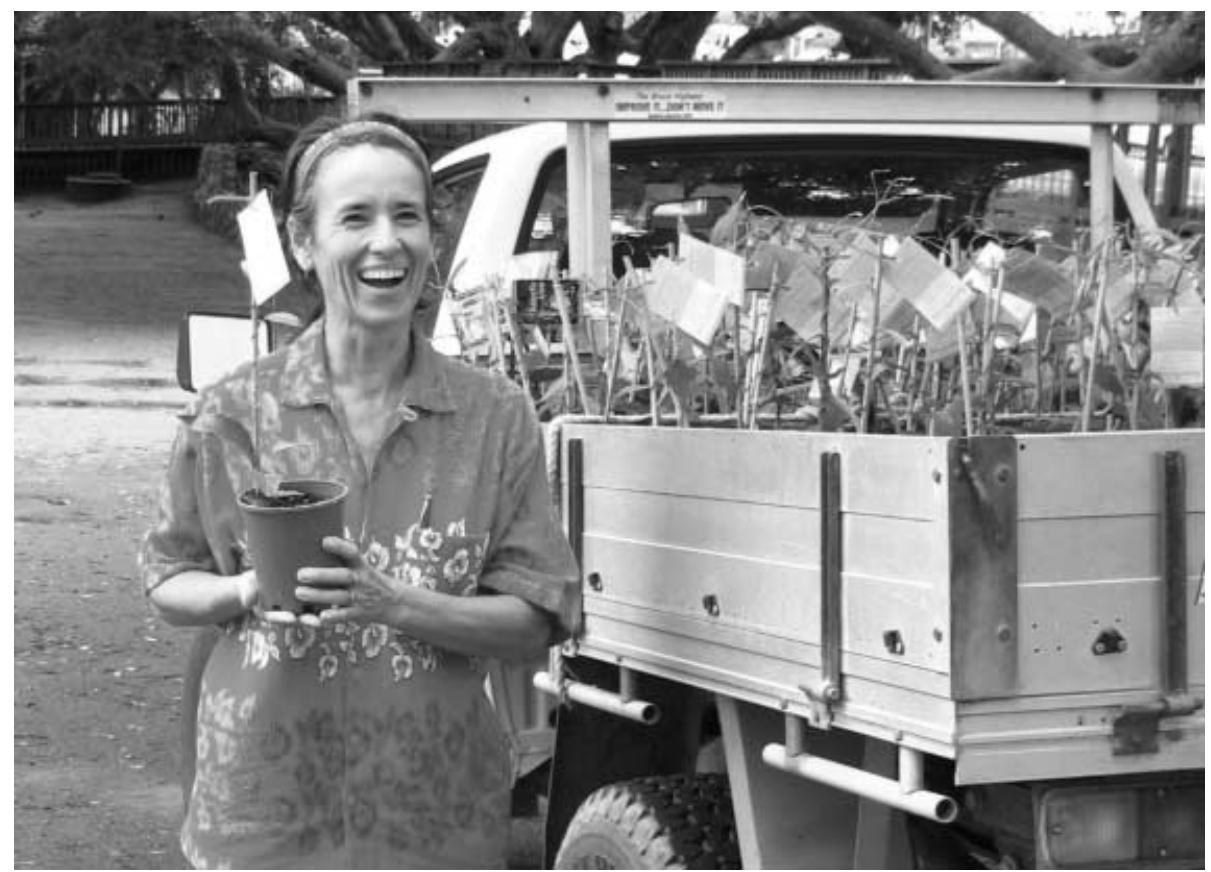

Figure 6. Eva Ford with a truckload of Richmond Birdwing Vines at Eumundi, south-east Queensland. Involvement of private landholders and the community in the conservation of the Richmond Birdwing is critical for raising awareness and securing the future of the species.

activities can be seen as Richmond Birdwing populations appear to be recovering locally.

\section{Training and community workshops}

The Network hosts talks, field workshops and community workshops (in each shire) and publishes illustrated newsletters for members with information on the Richmond Birdwing and its food plants.

The first of a series of community workshops, a training workshop held at Maleny, aimed to introduce the conservation concerns to the Land for Wildlife Officers from each municipality in south-eastern Queensland. In 2006/ 2007 , more than six talks or field events were hosted by the Network members. The major topics for the workshops are vine identities (using Williams \& Harden 1980), how to distinguish the 'look-alike' vines and the Dutchman's Pipe Vine, with demonstrations of recording and mapping wild and planted vines on the Network's database. Each participant receives a copy of the Network Newsletter
Supplement containing an illustrated background to the conservation project, illustrations of the Richmond Birdwing Butterfly, its life history and its food plants.

\section{Field days}

Field days have been very successfully hosted, especially by members who have demonstrated the recovery process on their private land. The bestdemonstrated examples of recovery were at Beerwah, south-east Queensland where two property owners, Arthur Powter and Ray Seddon, have established colonies of the Richmond Birdwing Butterfly by judicious planting, occasional fertilizing of the food plants and removing Dutchman's Pipe Vine.

\section{Control of Dutchman's Pipe Vine}

Commencing with the Double Helix Science Club Project, community groups and school students in NSW participated in 'search and destroy' missions aimed at removing or poisoning Dutchman's Pipe Vine from 


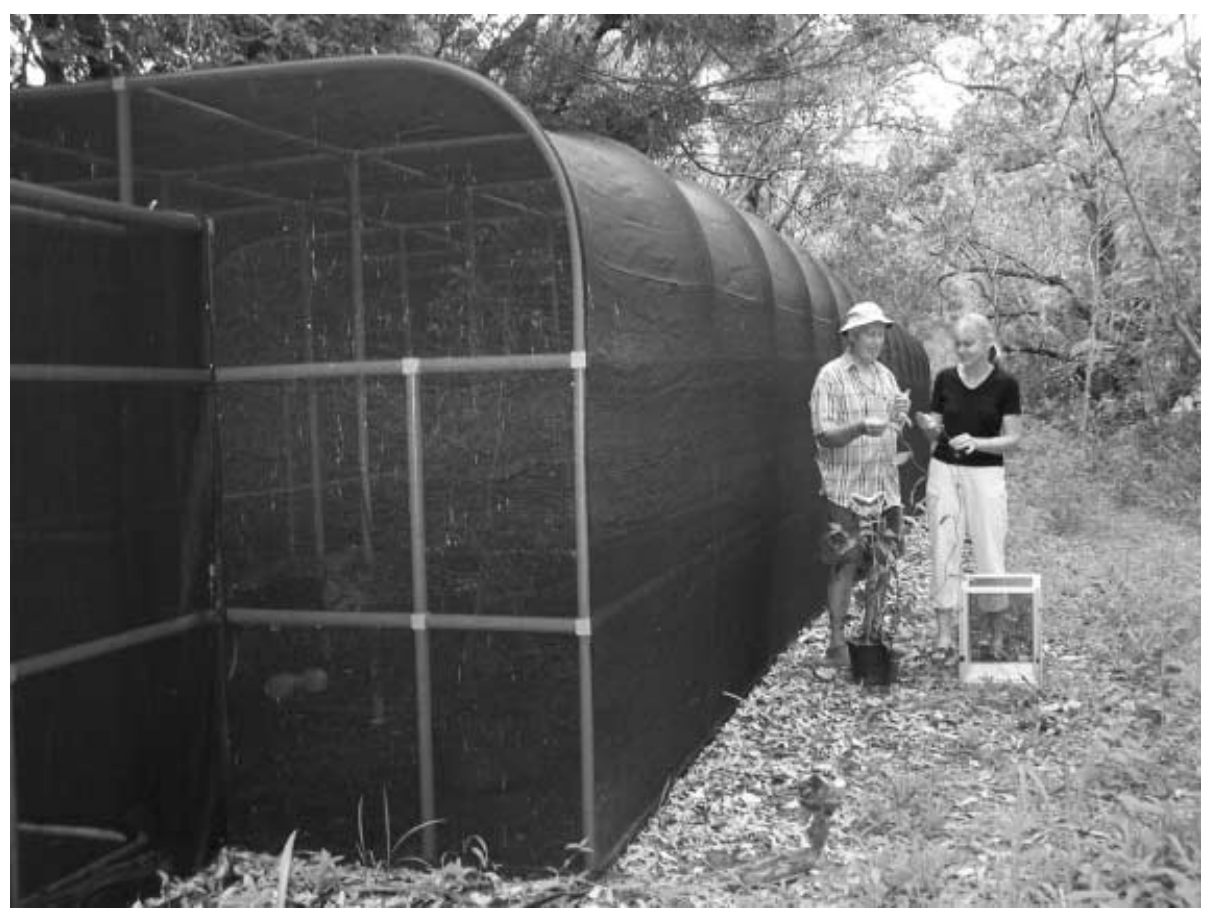

Figure 7. Prof Graeme Wilson (Moggill Creek Catchment Group) and Janet Richardson (Richmond Birdwing Recovery Network) examining larval food vines at the captive rearing flight cage at Gold Creek Reserve, Brisbane. The cage is used to study inbreeding depression in the Richmond Birdwing and is a partnership project between the Network and the Qld Environmental Protection Agency.

the whole region. These efforts have been remarkably successful, especially in northern NSW where this weed is now rarely seen in the suburbs or national parks. In Queensland, removal of Dutchman's Pipe Vine remains a priority and in more closely managed localities, removal has been very successful leading to reduction below the estimated threshold for Richmond Birdwing survival (based on proportions of eggs deposited on the native vine compared to the Dutchman's Pipe Vine). In some extensive Richmond Birdwing habitats such as in the Connondale Ranges, however, eventual eradication may not be feasible.

\section{Issues and emerging and future directions}

\section{Genetic and propagation issues for the food plant}

Permits are required to collect plant material from the wild and a permit to propagate, issued by the Queensland Parks and Wildlife Service, is required by anyone wishing to grow the vines for sale. Selection of stock for native plantings requires careful thought as introductions from too-distant sources may pose risks of genetic dilution from outbreeding, while propagating plants from too-small populations may result in inbreeding depression. As previously mentioned, because the local stocks of the food plant were already so depleted, we were advised that propagation from these were likely to heighten the already present risk of inbreeding and that some outcrossing may therefore be necessary for the survival of the vines. We determined that the most ecologically effective approach to conserve both the vine and the butterfly was to collect propagation material from a wider range of somewhat moredistant stocks.

The details of this approach, however, evolved over time. In the initial trials for the project, seeds of food vines were collected from cultivated plants that most readily resisted damping off in the belief they would be most amenable to cultivation. Subsequently, seeds were propagated from locations as near as possible to the areas to be planted (but not so near that they would risk further inbreeding). These sources, however, proved to be insufficient to meet the need to reconnect habitats. This led to the substantial collection of material from between Nerang and Tamborine Mountain, Queensland and near Lismore, NSW for planting between Brisbane and the NSW border (Box 2). Since 2005, two 'regions' were identified. Seeds were collected from Beerwah on the Sunshine Coast for distribution to areas north of Brisbane; while plants from seeds originally from Tamborine Mountain and Nerang were distributed south of Brisbane.

No evidence has been found of inbreeding depression in cultivated plants and there is some evidence that capsules have increased on the cultivated vines when compared with their abundance on wild vines. Interestingly, reports received suggest that seed capsules are formed most frequently on planted and wild vines where planted vines have been cultivated over the last 5 years (A. Powter, R. Seddon, pers. comm.). If this is the case, it may be due to outcrossing or an increase in effectiveness of pollinator midges.

In 2008, the Network has established a small scholarship to a student to commence studies on variation in DNA within or between populations of the Richmond Birdwing Vine. Based on the outcomes of these studies of genetic variation (and recent workshops on the topic), more attention is planned for propagating 'local' vines for distribution. Cutting grown vines and possibly tissue cultures will be used to propagate localized genetic material in sufficient quantities for replanting. However, the immense loss of Richmond Birdwing habitats, and absence of seeds from small sites will provide a serious challenge. Few seed capsules have been seen on wild vines since 1997, probably an effect of prolonged drought on capsule retention or the pollinators. During drought, capsules shrivelled and fell 
without maturing, limiting their availability from wild vines. Tube stocks were unsuitable for direct planting and only vines held for about 2 years in pots $(>8 \mathrm{~cm})$ survived adequately after planting. The destruction of suitable rainforest has continued in coastal areas north of Brisbane and no wild vines are known to have survived between Kin Kin Creek and Maryborough, representing one third of the original range.

\section{Need for captive rearing}

Inbreeding of the butterfly, indicated by an abundance of sterile eggs, is suspected to be causing local extinctions at two localities. This has prompted experiments to determine if a simple method can be used to enhance the genetic quality at in-bred sites and to promote outcrossing as a preliminary step to establishing adequate corridors for adults. A relatively new project, Captive rearing of the Richmond Birdwing Butterfly: A feasibility study on inbreeding depression, is being investigated by the Network in partnership with Queensland's Environmental Protection Agency (EPA). To follow on from observations by Orr (1994), two captive populations, one at David Fleay Wildlife Park on the Gold Coast and the other at the Gold Creek Reserve in the western suburbs of Brisbane, are being investigated using widely separated founders in caged mating trials (Fig. 7). Females reared from pupae are to be mated with males collected from localities at least $40 \mathrm{~km}$ distant, based on the maximum dispersal range of individual females of about $30 \mathrm{~km}$ (observed maximum distance from breeding site). This spacing $(30 \mathrm{~km})$ is thought adequate to avoid any inbreeding depression occurring in the butterfly and the only challenges will be to obtain the needed unmated females, to mate and feed them in captivity and to induce them to oviposit on food plants in the cages.

The egg hatching and larval development will be monitored under controlled conditions for mortality or disease of stages. Pending the success of these trials, young third or fourth instar larvae will be released at the two localities where inbreeding depression is suspected.

\section{Need for improving conservation status within formal reserves}

A significant finding from the Network's mapping project is that only five national parks in the northern region each contain more than 200 wild vines. The remainder are on private property where there is little protection unless nature refuge status is designated. Although formal mapping as a 'Regional Ecosystem' in Queensland affords some protection for privately owned sites, mapped sites are not always secure from disturbance and many highly fragmented sites are not officially mapped. This means that Richmond Birdwing habitats continue to be destroyed at an alarming and unsustainable rate.

It is thought provoking that in Queensland, where the Richmond Birdwing and its food plant once ranged from Maryborough to the NSW border, the number of national parks giving security of tenure for the food plant and sustaining breeding by the Richmond Birdwing are few. This region has approximately 10 national parks supporting suitable ecosystems but only five of these support the lowland food plant: Great Sandy (Kin Kin/Elanda), Connondale, D'Aguilar (Mount Mee), Tamborine Mountain and Burleigh Heads. Of these, only Connondale National Park has sufficient numbers of food plant to sustain the Richmond Birdwing Butterfly.

In an effort to address this issue, an active programme at a Section of Great Sandy National Park by EPA staff (R. Winter, pers. comm.) has commenced cultivating local Birdwing Butterfly Vines for replanting. This is the first such restoration project in a national park in south-eastern Queensland. A second project is being considered at Burleigh Heads, which aims to remove Dutchman's Pipe Vine and other weeds and replant Birdwing Butterfly Vines (L. Caddick, pers. comm.).
Communication challenges within a widely dispersed membership

Communication between interested members of the community has been difficult for the recently formed Network. Membership is spread from near Noosa Shire to the NSW border and inland to Toowoomba. Technical information about the butterfly and queries relating to cultivation of the food plants have required constant and coordinated responses, difficult for members of a voluntary organization to manage. Costs of producing newsletters, postage and other overheads have sometimes been difficult to cover from members' subscriptions alone. There has been no alternative but to seek considerable contributory grants to cover the costs of workshops and some publications.

\section{Drought and climate change issues}

The impacts of prolonged drought have been detrimental to all aspects of the recovery activities in south-eastern Queensland since 1997. Rainfall has been low and irregular until August 2007. Soil moisture has decreased everywhere and the changes in water tables have killed healthy vines in several places including rainforest. At Burleigh Heads National Park, vines more than 20 years old died from desiccation. Where older vines have survived because of their larger root systems or moisture retained beneath rocks, leaf toughness has increased and the number of butterfly larvae able to survive on larger vines is decreasing because of lack of palatable leaves and the rate of cannibalism has increased. Cannibalism frequently occurs in the early instars of Richmond Birdwing larvae, especially when soft leaves are in short supply (Sands et al. 1997).

Climate change, accompanied in subtropical Australia by periods of prolonged drought, continues to challenge recovery actions for the Richmond Birdwing Butterfly and its food plants. However, methods are 
being developed to assist survival of the vines and promote their quality during periods of drought. In gardens, Birdwing Butterfly Vines can be watered and fertilized, keeping vines alive and leaves soft enough for young larvae to feed and survive. Community propagation and care of vines is proving to be the most significant means of promoting survival of the butterfly. By maintaining small but viable colonies, the butterflies are able to opportunistically return to breed in natural bushland, when moisture conditions are temporarily normal.

\section{Ongoing need for recovery plan}

A draft recovery plan was prepared in 1996 by Don Sands and Sue Scott, submitted to the Queensland Parks and Wildlife Service for comment. However, a major objective throughout the duration of the Richmond Birdwing project has been to gain a deeper understanding of key threatening processes and the feasibility of addressing them in a revised recovery plan. A revised plan would need to address all the issues associated with the conservation of the Richmond Birdwing Butterfly (including the conservation needs of the Birdwing Butterfly Vine) and will require initial input and implementation support from all relevant governments.

High priorities for the recovery plan include addressing issues of tenure of remaining intact habitats, impacts of climate change on the insect stages and vines, and inbreeding depression in the butterfly itself. Although the plan would need to continue to prioritize protection of natural habitats from disturbance on public and privately owned land and to prevent further contractions in the range of the butterfly, addressing inbreeding depression is likely to continue to require filling gaps in larval food vine distribution, taking into consideration the needs of the pollinating midge.The most urgent need is in Queensland, where there is ongoing destruction of small habitat fragments which are known as very important breeding sites, but are often too small to attract conservation actions by the authorities.

\section{Concluding comments}

Insect conservation has been hindered by poor identifications, failure to understand threats and sound management practices (Sands 1999) resulting in neglect of effective recovery actions. Many insects are difficult to observe or monitor and their life histories are complex when compared with vertebrates. This project, however, has allowed members of the community to observe the local losses and recoveries of a large and easily recognized invertebrate species. Its interactions with plants and other invertebrates have been observed first-hand by school students and adult environmentalists. Home gardeners and bush regenerators have participated in most of the recovery activities and observe the outcomes of their efforts towards recovery of the butterfly and its food plants. Local councils and other authorities have been supportive, by helping to protect and rehabilitate small habitat fragments. Most recently, Caloundra City Council on the Sunshine Coast, Queensland, has dedicated a significant area of rainforest to the Richmond Birdwing and has established an education deck, surrounded by planted specimens of Birdwing Butterfly Vine. Landcare groups continue to receive government financial assistance, often in partnership with the Network, to rehabilitate their local bushland and eradicate the poisonous Dutchman's Pipe Vine.

The four plant nurseries sponsored by the Network have developed excellent methods for propagating Birdwing Butterfly Vine for planting in corridors from the Gold Coast to the Sunshine Coast. Standards they have set for the quality of vines ensure maximum chances of restoring suitable habitats in bushlands and gardens throughout the former range of the butterfly.

Although the involvement of the community in the conservation of the Richmond Birdwing has been critical for raising awareness and securing its future outside the protected area network, national parks and nature reserves provide the most important land tenures and security for protecting insect refuges in Australia. Yet these reserves have not yet been systematically surveyed to find 'what is being protected' (Sands \& New 2002b). The first step in the formal assessment requires a determination of what threatening processes, if any, exist in these areas.

\section{Acknowledgements}

Thanks is extended to Bob Moffatt who helped to initiate, design and implement the schools' programme in northern NSW. Network Member, Hugh Krenske is especially acknowledged for his work mapping food plant vines. Other Network Members, Rosie Booth, Dale Borgelt, Vanessa Bugg, Dick Bull, Gary Einam, Eva Ford, Ian Gynther, Chris Hosking, Phil Moran, Dawn Muir, Janet Richardson, Sue Scott, Ray Seddon, Greg Siepen, Alan Scott and Graeme Wilson are thanked for their significant contributions. The project has been dependent upon financial and in-kind contributions from government and community. During the first stage of the Project, the Double Helix Science Club received financial support from Brisbane Radio Station $4 \mathrm{BH}$ and the Southbank Corporation to develop a portable design leaf penetrometer and greenhouse.The World Wide Fund for Nature and National Heritage Trust awarded a Threatened Species Community Grant, Bayer Australia supported the 'Adopt-aCaterpillar Scheme', NSW National Parks \& Wildlife Service, the Double Helix Science Club and several community groups including The Hut Environment and Community Association Inc., provided in-kind support. In the second stage of the project, the Network has received support from the regional municipal Councils, South-east Queensland Catchments, the Voluntary Environment and Heritage Organizations Program, Brisbane City Council, Landcare 
Queensland and the Volunteer Small Equipment Grants. The workshops were supported by municipal councils, South-east Queensland Catchments, Queensland Landcare Foundation, several Catchment and Landcare Groups. Scientific staff of the Queensland Herbarium and Environment Protection Agency, E. M. Ross, W. McDonald, Dr Julia Playford, and Dr C.A. McConchie, CSIRO Plant Industry provided advice on genetics and distribution of cultivars. Anonymous donors have also provided muchneeded support to the Network. I thank Paul Grimshaw who has helped in various ways throughout the project from its beginning, and for willingly provided me with excellent botanical and ecological expertise, participation in the field and enthusiastic support.

\section{References}

Braby M. F. (2000) Butterflies of Australia. Their Identification, Biology and Distribution. CSIRO, Melbourne, Vic.

Common I. F. B. and Waterhouse D. F. (1981) Butterflies of Australia. Angus and Robertson, Sydney, NSW

Forster P. I., Bostock P. D., Bird L. H. and Bean A. R. (1992) Vineforest Plant Atlas for South-East Queensland. Queensland Herbarium, Brisbane, Qld.

Harden G., McDonald B. and Williams W. (2007) Rainforest Climbing Plants: A Field Guide to Their Identification. Gwen Harden Publishing, Nambucca Heads, NSW.

Haugam J. and Low A. M. (1979) A Monograph of the Birdwing Butterflies, Vol. I, Part 2. Scandanavian Science Press, Klampenborg, Denmark.

Illidge R. (1927) Brisbane butterflies of the family
Papilionidae. Queensland Naturalist 6, 3339.

Nally S. (2000) Paralucia spinifera. Lithgow's endangered copper butterfly. Community education and involvement program annual report. NSW National Parks and Wildlife Service, Lithgow, NSW.

New T. R. (1997) Exploitation and conservation of butterflies in the Indo-Pacific region. In: Conservation and the Use of Wildlife Resources (ed. M. Bolton), pp. 97-109. Chapman \& Hall, London.

New T. R. (2002) Birdwing butterfly conservation: Does it have wider values? In: Conservation of Birdwing Butterflies (eds D. P. A. Sands and S. Scott), pp. 8-13. SciComEd Pty Ltd, Marsden, Qld.

Orr A. G. (1994) Inbreeding depression in Australian butterflies: Some implications for conservation. Memoirs of the Queensland Museum 36, 179-184.

Parsons M. J. (1992) The world's largest butterfly endangered: The ecology, status and conservation of Ornithoptera alexandrae (Lepidoptera: Papilionidae). Tropical Lepidoptera Supplement 1, 33-60.

Parsons M. J. (1996) New species of Aristolochia and Pararistolochia (Aristolochiaceae) from Australia and New Guinea. Botanical Journal of the Linnean Society 120, 199-238.

Payne A. and Lundie-Jenkins G. (1999) Draft Recovery Plan for the Bulloak Jewel Butterfly (Hypochrysops piceata) 1998-2002. Queensland Parks and Wildlife Service, Brisbane, Old.

Ponder W. and Lunney D. (eds) (1999) The other 99\%. The Conservation and Biodiversity of Invertebrates. Transactions of the Royal Zoological Society of New South Wales, Sydney, NSW.

Rainbow W. J. (1907) A Guide to the Study of Australian Butterflies. Lothian, Melbourne, Vic.

Raven P. H. and Yeates D. K. (2007) Australian biodiversity: threats for the present, opportunities for the future. Australian Journal of Entomology 46. 177-187.

Ross E. M. (2007) Aristolochiaceae. Flora of Australia 2, 256-258, 458

Sands D. P. A. (1962) Papilio priamus richmondius. Communication. Entomology Section, Royal Zoological Society of NSW 23, 61.

Sands D. P. A. (1999) Conservation of Lepidop- tera: Assessment, threatening processes and recovery actions. In: The Other $99 \%$. The Conservation and Biodiversity of Invertebrates (eds W. Ponder and D. Lunney), pp. 382-387. Royal Zoological Society of New South Wales, Mosman, NSW.

Sands D. P. A. and New T. R. (2002a) The Action Plan for Australian Butterflies. Environemt Australia, Canberra, ACT.

Sands D. P. A. and New T. R. (2002b) Coordinated invertebrate surveys in Australia's national parks: an important tool in refining invertebrate conservation management. In: Invertebrate Biodiversity and Conservation. Records of the South Australian Museum, Monograph Series (eds A. D. Austin, D. A. Mackay and S. J. B. Cooper), pp. 203-208. South Australian Museum, Adelaide, SA.

Sands D. P. A. and Scott S. (1999) Conservation and recovery of the Richmond Birdwing Butterfly, Ornithoptera richmondia and its lowland food plant, Pararistolochia praevenosa. In: Rainforest Recovery for the New Millennium. Proceedings of the WWF Australia 1998 South-East Queensland Rainforest Recovery Conference (ed. B. Boyes), pp. 124-132. WWF, Tannum Sands, Qld.

Sands D. P. A. and Scott S. (2002) The Richmond Birdwing Butterfly (Ornithoptera richmondia [Gray]). In: Conservation of Birdwing Butterflies (eds D. P. A. Sands and S. Scott), pp. 32-47. SciComEd Pty Ltd, Marsden, Qld.

Sands D. P. A., Scott S. E. and Moffatt R. (1997) The threatened Richmond Birdwing butterfly (Ornithoptera richmondia [Gray]): A community conservation project. Memoirs of the Victorian Museum 56, 449-453

Stanley T. D. and Ross E. M. (1983) Flora of SouthEast Queensland, Vol. 1. Department of Primary Industries, Brisbane, Qld.

Straatman R. (1962) Notes on certain Lepidoptera ovipositing on plants which are toxic to their larvae. Journal of the Lepidopterists Society 16. 99-103.

Waterhouse G. A. (1932) What Butterfly Is That? Angus and Robertson, Sydney, NSW.

Williams J. B. and Harden G. J. (1980) Rainforest Climbing Plants. University of New England, Armidale, NSW.

Zborowski P. and Edwards T. (2007) A Guide to the Australian Moths. CSIRO, Melbourne, Vic.

Summary The Richmond Birdwing Butterfly, restricted to subtropical areas of Australia, is threatened with extinction in the Queensland part of its range because of clearing and fragmenting rainforests containing its larval food vines. Habitat fragmentation and drought have exacerbated risks of inbreeding depression and a range of other threats exist, including invasions of the exotic Dutchmans Pipe Vine which is toxic to Richmond Birdwing larvae. This article outlines the Richmond Birdwing Butterfly project from its beginnings in the Double Helix Club project and recently the Richmond Birdwing Recovery Network. It provides details of the biology of the butterfy and its food vines, as well as discussing elements for consideration in a future recovery plan including (i) protecting the remaining breeding sites; and, for the shorter term (ii) continuing to propagate and plant food plants at appropriate localities that previously supported the butterfly. 